\title{
Enhancement of Cellulose Rich Organic Matter Degradation by Inoculation with Streptomyces sp. Strains
}

\author{
Simonida Djurić ${ }^{1}$, Timea Hajnal-Jafari ${ }^{1 *}$, Dragana Stamenov ${ }^{1}$, Dejan Vidanović ${ }^{2}$, Vuk Vračar ${ }^{1}$ and Biljana Najvirt $^{1}$ \\ ${ }^{1}$ Faculty of Agriculture, University of Novi Sad, Novi Sad, Serbia \\ ${ }^{2}$ Veterinary Specialist Institute "Kraljevo”, Kraljevo, Serbia \\ "For correspondence: mikrobiologija@polj.uns.ac.rs \\ Received 09 February 2021; Accepted 23 April 2021; Published 10 July 2021
}

\begin{abstract}
Microbial degradation of organic matter is a vital part of carbon cycle in nature. Actinobacteria play an important role in the decomposition of cellulose rich organic matter (CROM). Streptomyces spp. are abundant in soil, produce various secondary metabolites and secrete extracellular enzymes. The aim of this research was to isolate and select Streptomyces strains with the best cellulose degradation abilities. Out of total 32 actinobacteria isolates, four Streptomyces strains (CA1, CA10, PA2 and PA7) were subjected to morphological, physiological, biochemical characterization and molecular identification. CROM degradation potential of the strains was investigated on straw and beech briquettes as well as on legume based substrate in in vitro condition. Streptomyces strains CA1 and CA10 showed the best cellulose production and starch hydrolysis abilities, followed by strains PA2 and PA7. Strain CA1 was also positive to production of pectinase enzymes. Streptomyces zaomyceticus CA1 and S. tanashiensis CA10 were used as inoculants, which degraded the raw cellulose from 38.38 to $81.69 \%$ in the investigated substrates (straw, beech, legume), during a 30-day incubation experiment. CROM inoculation with the selected Streptomyces strains improved and accelerated its degradation in controlled conditions. (C) 2021 Friends Science Publishers
\end{abstract}

Key words: Cellulose degradation; Actinobacteria; Streptomyces sp.; Inoculation; Enzymes

\section{Introduction}

Cellulose is a major component of plant biomass and the most common organic compound on earth (Gonzalo et al. 2016). By chemical composition, cellulose is a linear polysaccharide composed of glucose molecules connected with $\beta$ 1-4 glycosid bonding (Hussain et al. 2017). Plants produce $4 \times 10^{9}$ tons of cellulose per year (Abedin 2015). The remains of crops rich in cellulose make up 50\% of the agricultural organic matter dry mass, whose microbial degradation is a vital part of carbon cycle in the biosphere. The decomposition of that biomass is done by cellulolytic bacteria, fungi and actinobacteria (Haruta et al. 2002). Microorganisms produce hydrolytic enzymes called cellulases, a complex of three important enzymes that act synergistically thanks to the crystalline and amorphous complex structure of cellulose. These enzymes hydrolyze cellulose into cellobiosis, glucose and oligo-saccharides.

Actinobacteria play an important role in the degradation of cellulose rich organic matter. About $90 \%$ of the total population of actinobacteria is species of the genus Streptomyces (Poopal and Laxman 2009). Streptomyces are slowly growing filamentous bacteria, abundant in soil, but also in environments with harsh conditions since they are highly adaptable due to their thermo tolerance and spore forming ability. The genus is mainly known and researched for their production of various secondary metabolites such as antibiotics and volatile compounds (Elardo et al. 2009). But they also secrete extracellular enzymes (cellulases and proteases). Cellulose-degrading activity was found in the genus Streptomyces in various species and strains (Prasad et al. 2013; Devi et al. 2018). Research of Berlemont and Martiny (2013), aimed at genomic analyses of 5,123 bacterial genomes from 8 major phyla. It was demonstrated that nearly all Streptomyces genomes contained CarbohydrateActive Enzymes (CAZy). Many authors showed that Streptomyces could be a source of CAZy and used in various enzyme based technologies (Saratale et al. 2012; Soeka et al. 2019). However, the introduction or Streptomyces strains to organic matter in order to enhance its decomposition is not enough investigated. Zhao et al. (2017) showed that inoculation of compost with Streptomyces strains H1, G1, G2, and Actonobacteria T9, at different stages improved cellulase activities and accelerated the degradation of cellulose. Streptomyces albus BM292 exhibited great potential for bioaugmentation of compost (Jurado et al. 2014). Olson et al. (2012) also argued that 
actinobacteria could be used as inoculants in which cellulose was degraded into desired products.

Therefore, the aim of this research was to isolate and select Streptomyces strains with good cellulose degrading abilities. Moreover, another object of the study was to evaluate the CROM degradation potential of the selected strains on different cellulose rich substrates in in vitro condition.

\section{Materials and Methods}

\section{Isolation of Streptomyces strains}

Microorganisms were isolated from soil pseudogley (locality village Maovi near Šabac - Pocerina: N $44^{\circ} 41^{\prime} 43,73$ '; E 19 $37^{\prime} 31,04$ ') having the following characteristics: $1.67 \% \mathrm{CaCO}_{3} ; 5.19 \%$ humus; $0.26 \% \mathrm{~N}$; $177.5 \mathrm{mg} \mathrm{P}_{2} \mathrm{O}_{5}$ in $100 \mathrm{~g}$ of soil; $105.34 \mathrm{mg} \mathrm{K}_{2} \mathrm{O}$ in $100 \mathrm{~g}$ of soil; $\mathrm{pH}$ in $\mathrm{H}_{2} \mathrm{O}$ 6.78; $\mathrm{pH}$ in $\mathrm{KCl} 5.80$.

A $10 \mathrm{~g}$ of soil sample was suspended in $90 \mathrm{~mL}$ of 0.1 $\mathrm{M} \mathrm{MgSO}_{4} \times 7 \mathrm{H}_{2} \mathrm{O}$ buffer and shaken for $10 \mathrm{~min}$ at $180 \mathrm{rpm}$ on a rotary shaker. The soil suspension was then diluted in four-fold steps in glass tubes to an end point dilution of $10^{-}$ $5.100 \mu \mathrm{L}$ of the dilutions $\left(10^{-1}\right.$ to $\left.10^{-5}\right)$ were spread onto Synthetic agar (glucose $10 \mathrm{~g} \mathrm{~L}^{-1}, \mathrm{NaNO}_{3} 10 \mathrm{~g} \mathrm{~L}^{-1}, \mathrm{~K}_{2} \mathrm{HPO}_{4}$ $10 \mathrm{~g} \mathrm{~L}^{-1}, \mathrm{KCl} 10 \mathrm{~g} \mathrm{~L}^{-1}, \mathrm{MgSO}_{4} \times 7 \mathrm{H}_{2} \mathrm{O} 10 \mathrm{~g} \mathrm{~L}^{-1}$, agar 15 $\mathrm{g} \mathrm{L}^{-1}$ ), and incubated at $28^{\circ} \mathrm{C}$ for $7-10$ days. Powdery colonies which were established as gram-positive, filamentous bacteria that form a branching network of filaments and produce spores were picked.

\section{Physiological and biochemical characterization of Streptomyces isolates}

To determine the carbon source utilization, isolates were grown on Hugh-Lifsson medium (pepton $2 \mathrm{~g} \mathrm{~L}^{-1}, \mathrm{~K}_{2} \mathrm{HPO}_{4}$ $0.3 \mathrm{~g} \mathrm{~L}^{-1}, \mathrm{NaCl} 5 \mathrm{~g} \mathrm{~L}^{-1}$, carbon source $10 \mathrm{~g} \mathrm{~L}^{-1}$, brom-thymol blue $0.03 \mathrm{~g} \mathrm{~L}^{-1}$, agar $3 \mathrm{~g} \mathrm{~L}^{-1}$ ) with different carbon source (glucose, fructose, lactose, sucrose, xylose). The change in color, from green to yellow, indicated a positive reaction.

The isolates ability to grow at different temperatures $\left(5,15,28,37\right.$ and $\left.45^{\circ} \mathrm{C}\right)$, on substrates of different acidity (pH 5, 7 and 9) and on substrates with different $\mathrm{NaCl}$ concentrations $(3,5$ and $7 \%$ ) were monitored on potato dextrose agar (PDA). The isolates were incubated for 7 days. The diameter of the isolates colony was measured and compared with the control.

The selected isolates were tested for their resistance to antibiotics (penicillin $10 \mu \mathrm{g} \mathrm{mL}^{-1}$, novobiocin $5 \mu \mathrm{g} \mathrm{mL}^{-1}$, tetracycline $30 \mu \mathrm{g} \mathrm{mL}^{-1}$, chloramphenicol $30 \mu \mathrm{g} \mathrm{mL}^{-1}$ ) by disk-diffusion method (Amna et al. 2019). After seven days of incubation at $28^{\circ} \mathrm{C}$, the results were recorded by measuring the diameter of the inhibition zone around the disks. Completely tolerant isolates were denoted by "-no zone; + zone of inhibition of 0-2 mm; ++ zone of inhibition of $2-5 \mathrm{~mm}$.

\section{In vitro assay of extracellular enzymatic activities}

Production of pectinase was tested by the method of agar plates on pectin agar. Incubation lasted $24 \mathrm{~h}$ at $37^{\circ} \mathrm{C}$, after which colonies were overflowed with lugol. The appearance of uncolored zones around the colony was the evidence of pectinase activity (Soriano et al. 2000; Soares et al. 2001). Cellulase production was performed by flooding a solution of Congo-red $\left(1 \mathrm{mg} \mathrm{cm}^{-3} \mathrm{H}_{2} \mathrm{O}\right)$ on isolates grown on CMC agar (Kasing 1995). The presence of halo zone around the colony was the proof of the cellulose decomposition. Starch hydrolysis was assayed on starch agar, following the protocol as reported by Cappuccino and Sherman (1992).

Urea degradation was tested on Christensen's urea agar (meat peptone $1 \mathrm{~g} \mathrm{~L}^{-1}$, dextrose $1 \mathrm{~g} \mathrm{~L}^{-1}, \mathrm{NaCl} 5 \mathrm{~g} \mathrm{~L}^{-1}$, $\mathrm{Na}_{2} \mathrm{HPO}_{4} 1.2 \mathrm{~g} \mathrm{~L}^{-1}, \mathrm{KH}_{2} \mathrm{PO}_{4} 0.8 \mathrm{~g} \mathrm{~L}^{-1}$, phenol-red $0.012 \mathrm{~g} \mathrm{~L}^{-}$ 1 , agar $15 \mathrm{~g} \mathrm{~L}^{-1}$, urea $20 \mathrm{~g} \mathrm{~L}^{-1}$ ). The appearance of the reddish color in the medium indicates the ureolytic activity of the isolate. Lipase production was examined on medium (pepton $10 \mathrm{~g} \mathrm{~L}^{-1}, \mathrm{NaCl} 5 \mathrm{~g} \mathrm{~L}^{-1}, \mathrm{CaCl}_{2} \times \mathrm{H}_{2} \mathrm{O} 0.1 \mathrm{~g} \mathrm{~L}^{-1}$, agar $15 \mathrm{~g} \mathrm{~L}^{-1}$ ) with Tween 80 addition. Formation the turbid zones around the colony are evidence of lipolytic activity. Hydrolysis of gelatin was tested on deep gelatinous agar (meat extract pepton broth (MPB) $+10-15 \%$ gelatin) (Aneja 2003). After incubation, degradation of gelatin in inoculated tubes was proof of the gelatinase activity.

Streptomyces isolates were screened for PGP activities on hydrogen cyanide $(\mathrm{HCN})$ induction medium (Tryptic Soy Broth $30 \mathrm{~g} \mathrm{~L}^{-1}$, Glycine $4.4 \mathrm{~g} \mathrm{~L}^{-1}$, agar $15 \mathrm{~g} \mathrm{~L}^{-1}$ ), chromazurol $\mathrm{S}$ (CAS) medium and tryptone broth (containing 5 mmol $\mathrm{L}^{-1}$ tryptophan) for HCN, IAA and siderophores production, respectively (Schwyn and Neilands 1987; FreyKlett et al. 2005; Etesami et al. 2015).

\section{Molecular identification}

Actinobacteria DNA extraction was performed using the Gene MATRIX Gram Plus and Yeast Genomic DNA Purification Kit (EURx Ltd.80-297, Gdansk Poland). The amount of DNA from four actinobacteria samples was determined on a QFX Fluorometer apparatus (Denovix Inc, Wilmington, USA). 16s rRNA gene sequences were obtained using two universal actinobacteria primers. The first primer pair was 27F AGAGTTTGATCMTGGCTCAG 1492R GGYTACCTTGTTACGACTT, while the second primer pair was S-C-Act-0235-a-S-20 GGCCTATCAGCTTGTTG S-C-Act-0878-a-ACG CCGG. After sequencing, two 1300 nucleotide length sequences and two 600 nucleotide length sequence were obtained. Further identification was performed using the BLAST algorithm into which the sequences were inserted (http://www.ncbi.nlm.nih.gov/genbank/).

\section{Incubation experiment}

The incubation experiment was performed on three different 
sources of organic matter - straw briquettes, beech briquettes, and legume mix (containing six different beans and peas' varieties mixture). The amount of different fractions in investigated substrates is presented in Table 1.

The substrates were sterilized in autoclave $(1 \mathrm{~h}$ at $\left.121^{\circ} \mathrm{C}\right) .10 \mathrm{~g}$ of each substrate were measured and placed in sterile Petri dish ( $9 \mathrm{~cm}$ diameter). The treatments were: 1. Control (water); 2. S. zaomyceticus CA1; 3. S. tanashiensis CA10. Each treatment contained three repetitions. A seven days culture of both strains was used. Spores were counted in the Neubauer chamber, and their number was calculated in $1 \mathrm{~mL}$ of liquid nutrient medium. By adding saline, the number was brought to $10^{6}$ spores in $1 \mathrm{~mL}$ of inoculums and $10 \mathrm{~mL}$ was used per treatment, respectively.

The incubation experiment lasted 30 days in controlled conditions (constant temperature $25^{\circ} \mathrm{C}$, moisture content was maintained at $60 \%$ field capacity). The amount of crude cellulose was determined by the filter bags method (Page et al. 1982) on the ANCOM 2000 apparatus. The percentage of crude cellulose was calculated using the formula:

$$
\% \text { crude cellulose }=100 \times(\mathrm{W} 3-(\mathrm{W} 1 \times \mathrm{C} 1) / \mathrm{W} 2
$$

Where $\mathrm{W} 1$ is the mass of the filter bag; W2 represents the mass of the sample; W3 is the mass of organic matter and $\mathrm{C} 1$ is the content-based correction factor.

\section{Statistical analyses}

The incubation experiment was conducted in a completely randomized block design with three replications. The data were subjected to analysis of variance (ANOVA) to evaluate the efficiency of Streptomyces strains application. The least significant difference test (Fisher LSD) was performed to compare the results between treatments at $\mathrm{P}>$ 0.05. Software Statistica, version 13.3 (TIBCO Software Inc.) was used for statistical analysis.

\section{Results}

\section{Selection and identification of Streptomyces strains}

Total 32 actinobacterial isolates were isolated. Based on colony morphology, color, size and appearance isolates were grouped. The isolates with whitish, compact, large to gigantic colonies with wavy edges were designated as possible Streptomyces isolates (11 isolates). Further microscopic observation proved the Gram positive, filamentous spore forming cells in four isolates with numbers CA1, CA10, PA2 and PA7. Those isolates were chosen for further physiological, biochemical characterization and genetic identification.

\section{Physiological characterization of Streptomyces strains}

To characterize the growth conditions, the selected strains were grown at the specified temperature $\left(5-45^{\circ} \mathrm{C}\right), \mathrm{pH}$
(5-9), and $\mathrm{NaCl}$ concentrations (3-7\%). Several C source (five sugars) and antibiotics were used to test $\mathrm{C}$ utilization and resistance, respectively (Table 2). The results showed that the best temperatures for growth were between $28^{\circ} \mathrm{C}$ to $37^{\circ} \mathrm{C}$ for all four Streptomyces strains. They grew well in neutral $\mathrm{pH}$ but also in highly alkaline medium, except strain PA7, indicating its quite wide $\mathrm{pH}$ tolerance. It was also found that the strains were not grown even at the lowest tested $\mathrm{NaCl}$ concentration (except CA1), suggesting that the strains might be halophobic. CA1 and PA7 used lactose and sucrose as C source, respectively. Only CA10 showed lack of antibiotic resistance towards tetracycline, penicillin and chloramphenicol.

\section{Biochemical characterization of Streptomyces strains}

Streptomyces strains CA1 and CA10 showed the best cellulose production and starch hydrolysis abilities, followed by strains PA2 and PA7 (Table 3). All four strains were weakly positive to urease test, and also to lipase production. Production of $\mathrm{HCN}$ is important for plant pathogen suppression. Only strain PA2 proved negative.

\section{Molecular identification}

All four actinobacterial samples were sequenced with two pairs of nucleotides to obtain a sequence of about 1,300 nucleotides in length. After sequencing, two isolates (PA2, CA10) obtained this length, while in PA7 and CA1 isolates, about 600 nucleotides were obtained, which was quite enough to perform the identification up to species level.

CA1 isolate obtained 608 nucleotide sequences. Based on the comparison with the existing sequences from BLAST, the isolate belonged to $S$. zaomyceticus. CA10 isolate obtained 1372 nucleotide sequences. Based on the comparison with the existing sequences from BLAST, the isolate belonged to $S$. tanashiensis. PA2 isolate obtained 1347 nucleotide sequences. Based on the comparison with the existing sequences from BLAST, the isolate belonged to S. ambofaciens. PA7 isolate obtained 633 nucleotide sequences. Based on the comparison with the existing sequences from BLAST, the isolate belonged to $S$. zaomyceticus.

\section{Incubation experiment}

Thirty-day incubation experiment showed that the amount of raw cellulose in the investigated substrates decreased in all treatments (Table 4).

Percent decrease of the raw cellulose content varied among treatments (Table 5). In straw briquettes treated with S. zaomyceticus CA1, the decrease compared to the amount at the beginning of the experiment was $69.65 \%$ while this reduction was $65.89 \%$ with the addition of $S$. tanashiensis CA10. By adding $S$. zaomyceticus to the beech based substrate, after a month of incubation, there was a $51.57 \%$ 
decrease in the amount of cellulose compared to the initial stage. S. tanashiensis also reduced the cellulose content by $56.49 \%$. In the legume-based substrate, the amount of raw cellulose was reduced by $81.32 \%$ after the addition of $S$. zaomyceticus CA1 (Fig. 1). S. tanashiensis CA10 decreased the amount of cellulose by $64.2 \%$ compared to the initial state.

\section{Discussion}

The Streptomyces strains were mesophylic, typical for the agroecological conditions of the region they originated from. This is in accordance with the research of Stamenov (2013), who determined that the optimal temperatures for actinobacteria growth were between 28 and $37^{\circ} \mathrm{C}$, while no isolate grew at 3 and $45^{\circ} \mathrm{C}$. Sreevidya et al. (2016) showed that four actinobacterial isolates grew on temperatures between 20 and $40^{\circ} \mathrm{C}$ and $\mathrm{pH}$ ranging between $\mathrm{pH} 7-11$. Our research showed that the tested strains were neither particularly good users of sugars (lactose by CA1 and sucrose by PA7) nor did they grow in medium with added $\mathrm{NaCl}$ (only CA1 grew at $3 \% \mathrm{NaCl}$ ). Those results are in contrast to those of Stamenov et al. (2016), who concluded that the Streptomyces isolates used glucose, galactose, fructose, sucrose, lactose and xylose as $\mathrm{C}$ source and grew in media with elevated salinity (added 3-7\% $\mathrm{NaCl}$ ). On the other hand, Dhanasekaran et al. (2009) found that Streptomyces DPTD-5 and S. bikiniensis used sucrose, lactose and fructose as carbon source. Antibiotic resistance test singled out only strain CA10 as susceptible towards antibiotics. In the work of Koushalshahi et al. (2012) noted differential sensitivity of Streptomyces isolates towards seven antibiotics including nitrofurantoin, nalidixic acid, gentamycin, erythromycin and rifampicin, while they were resistant to penicillin and ampicillin.

Our research showed that actinobacteria strains produced many extracellular enzymes, which participated in the mineralization of investigated organic matter. All four strains produced cellulase, amylase and lipase enzymes while one produced pectinase (CA1) and gelatinase (PA7). Aly et al. (2012) found that 20 out of 33 isolates of the genus Streptomyces sp. produced lipases. On the other hand, Dhanasekaran et al. (2009) found only one isolate, out of 20 to perform hydrolysis of lecithin, lipids, pectin and starch, which is in accordance with our results. Gopalakrishnan et al. (2011) also noticed that two of the five investigated actinomycetes produced cellulase and protease enzymes. Research by Alam et al. (2004) determined that different Streptomyces strains were capable of producing cellulolytic enzymes during growth on various cellulose substrates.

Statistically significant decomposition was achieved by addition of Streptomyces strains, though decrease of cellulose content in the watered treatment ranged between $24.23 \%$ in straw briquettes and $44.43 \%$ in beech briquettes. Those results could be attributed to the process of cellulose natural decomposition which occurs at a very low rate under
Table 1: Basic chemical composition of the substrates - fresh mass $\left(\mathrm{g} 100 \mathrm{~g}^{-1}\right)$

\begin{tabular}{lllll}
\hline Substrates & Dry matter & Moisture & Raw cellulose & Ash \\
\hline Straw briquettes & 92,06 & 7,94 & 39,40 & 7,06 \\
Beech briquettes & 92,26 & 7,74 & 55,63 & 1,04 \\
Legume mix & 91,81 & 8,19 & 29,65 & 8,85 \\
\hline
\end{tabular}

Table 2: Physiological characterization and growth conditions

\begin{tabular}{|c|c|c|c|c|}
\hline \multirow[t]{2}{*}{ Growth conditions } & \multicolumn{4}{|c|}{ Strain number } \\
\hline & CA1 & CA10 & PA2 & PA7 \\
\hline \multicolumn{5}{|l|}{ Temperature $\left({ }^{\circ} \mathrm{C}\right)^{*}$} \\
\hline 5 & - & - & - & - \\
\hline 15 & + & + & - & - \\
\hline 28 & ++ & ++ & ++ & + \\
\hline 37 & ++ & ++ & ++ & ++ \\
\hline 45 & - & - & - & - \\
\hline \multicolumn{5}{|l|}{$\mathrm{pH}^{*}$} \\
\hline 5 & - & ++ & ++ & - \\
\hline 7 & ++ & ++ & ++ & + \\
\hline 9 & ++ & ++ & + & - \\
\hline \multicolumn{5}{|l|}{$\mathrm{NaCl}$ concentration $(\%)^{*}$} \\
\hline 3 & + & - & - & - \\
\hline 5 & - & - & - & - \\
\hline 7 & - & - & - & - \\
\hline \multicolumn{5}{|l|}{ C source* } \\
\hline Glucose & - & - & - & - \\
\hline Fructose & - & - & - & - \\
\hline Lactose & + & - & - & - \\
\hline Sucrose & - & - & - & + \\
\hline Xylose & - & - & - & - \\
\hline \multicolumn{5}{|l|}{ Antibiotics resistance $* *$} \\
\hline Penicillin $10 \mu \mathrm{g} \mathrm{mL}^{-1}$ & - & + & - & - \\
\hline Tetracyclin $30 \mu \mathrm{g} \mathrm{mL}^{-1}$ & - & ++ & - & - \\
\hline Novobiocin $5 \mu \mathrm{g} \mathrm{mL}^{-1}$ & - & - & - & - \\
\hline Chloramphenicol $30 \mu \mathrm{g} \mathrm{mL}^{-1}$ & - & + & - & - \\
\hline
\end{tabular}

Table 3: Biochemical properties of Streptomyces strains

\begin{tabular}{lllll}
\hline Biochemical properties & \multicolumn{5}{c}{ Strain number } \\
\cline { 2 - 5 } & CA1 & CA10 & PA2 & PA7 \\
\hline Pectinase test & + & - & - & - \\
Cellulase production & +++ & +++ & + & + \\
Starch hydrolysis & +++ & +++ & + & + \\
Urease test & + & + & + & + \\
Lipase production & + & + & + & + \\
Gelatin hydrolyses & - & - & - & + \\
Production of HCN & + & + & - & + \\
IAA production & - & + & - & - \\
Siderophore production & - & - & - & - \\
\hline -negative; + weakly positive; ++ positive; ++++ strongly positive & \multicolumn{5}{c}{}
\end{tabular}

normal atmospheric conditions (Jeong et al. 2012). Thus, little is known about water solubility of cellulose and the reactions needed to break the hydrogen bonds which stabilize the structure of cellulose (Levi et al. 2016). It was demonstrated that $S$. zaomiceticus $\mathrm{CA} 1$ and $S$. tanashiensis CA10 were particularly good producers of both cellulases and amylases. The results obtained after the one month incubation experiment with CA1 and CA10 strains, showed that the amount of raw pulp decreased between $51.7 \%$ (from 554.4 to $268.5 \mathrm{mg} \mathrm{g}^{-1}$ ) to as much as $81.69 \%$ compared to the initial state (295.5 compared to $55.2 \mathrm{mg} \mathrm{g}^{-1}$ ). 
This coincided with the results obtained of Zhao et al. (2017), who showed accelerated degradation of cellulose by microorganisms. They added cellulolytic thermophilic actinobacteria to manure and corn straw at different periods (several inoculations during decomposition) and showed that inoculation led to an increase in cellulolytic enzymes activity, accelerated the degradation of cellulose, increased the content of humus substances and changed the structure of the actinobacteria community. In the work of Zhao et al. (2016) chicken manure was inoculated with Streptomyces sp. and Micromonospora sp during composting by different methods of inoculation. The inoculation significantly accelerated the degradation of manure, especially the cellulose fraction, which is consistent with the results of our research. Maximum reduction of raw cellulose content was achieved after inoculation of legume mix substrate with $S$. zaomyceticus CA1. In this perspective, Sanchez et al. (2017) concluded that it is necessary to develop technologies that should aim at improvement of the nutritional characteristics of compost. By the addition of nutrients from natural sources as well as microorganisms, the concentration of nutrients in compost that are available to plants could be increased. Varma et al. (2017) after a study on the microbial population involved in the degradation of ligno-cellulose during the composting of mixed organic waste (e.g. plant waste, manure fertilizer, dry leaves) concluded that combinations of waste materials had a great influence on microbial degradation of waste material and quality of final compost, due to their physical properties. Heterotrophic bacteria were predominantly active during the initial composting phase due to available organic matter, while actinobacteria were active during the degradation of lingo-cellulose fractions.

\section{Conclusion}

S. zaomyceticus CA1 and S. tanashiensis CA10, decreased the amount of the raw cellulose between 38.38 and $81.69 \%$ in all three investigated substrates (straw, beech, legume), during a 30 day incubation period. The selected strains showed a potential to promote the degradation of cellulose in the substrates. Their application in agriculture, as mineralization enhancer could speed up the biodegradation processes of cellulose rich OM in soil. It could also help to harvest different end products which are formed as a result of fermentation of various materials and wastes rich in carbohydrates.

\section{Acknowledgements}

This work was supported by the Ministry of Education, Science and Technological Development of the Republic of Serbia (Contract No. 451-03-68/2020-14/200117).

\section{Author Contributions}

SDj planned the experiments, THJ, DS and BN gathered
Table 4: Cellulose content in investigated substrates $\left(\mathrm{mg} \mathrm{g}^{-1}\right)$

\begin{tabular}{lllll}
\hline Substrate & Initial state & $\varnothing \mathrm{H}_{2} \mathrm{O}$ & $\mathrm{CA} 1$ & $\mathrm{CA} 10$ \\
\hline Straw briquettes & $392.1 \mathrm{~b}^{*}$ & $297.1 \mathrm{k}$ & $119.0 \mathrm{~h}$ & $133.7 \mathrm{~g}$ \\
Beech briquettes & $554.4 \mathrm{a}$ & $308.1 \mathrm{c}$ & $268.5 \mathrm{~d}$ & $241.2 \mathrm{e}$ \\
Legume mix & $295.5 \mathrm{k}$ & $165.2 \mathrm{f}$ & $55.2 \mathrm{j}$ & $105.8 \mathrm{i}$ \\
\hline \multicolumn{4}{l}{ *Different letters in subscripts indicate statistically significant difference according to }
\end{tabular}
Fisher LSD test $(\mathrm{p}<0.05)$

Table 5: Decrease of raw cellulose content compared to the initial state $(\%)$

\begin{tabular}{|c|c|c|c|}
\hline Substrate & $\varnothing \mathrm{H}_{2} \mathrm{O}$ & CA1 & CA10 \\
\hline Straw briquettes & 24.23 & 69.65 & 65.9 \\
\hline Beech briquettes & 44.43 & 51.57 & 56.49 \\
\hline Legume mix & 44.1 & 81.32 & 64.2 \\
\hline
\end{tabular}

Fig. 1: Substrate of legume mix: control (a) and treatment with $S$. zaomyceticus CA1 (b), 30 days after inoculation

and interpreted the results, VV and DV did the molecular analyses. DS statistically analyzed the data. SDj and THJ wrote the paper.

\section{Conflicts of Interest}

All authors declare no conflicts of interest

\section{Data Availability}

Not applicable in this paper

\section{Ethics Approval}

Not applicable in this paper

\section{References}

Abedin JI (2015). Isolation and identification of cellulose degrading bacteria from soil sample. Degree Dissertation. Brac University, Dhaka, Bangladesh

Alam MZ, MA Manchur, MN Anwar (2004). Isolation, purification, characterization of cellulolytic enzymes produced by the isolate Streptomyces omiyaensis. Pak J Biol Sci 7:1647-53

Aly MM, S Tork, S Al-Garni, L Nawar (2012). Production of lipase from genetically improved Streptomyces exfoliates LP10 isolated from oil contaminated soil. Afr J Microbiol Res 5:1125-1137

Amna S, B Sarfraz Din, Y Xia, MA Kamran, MT Javed, T Sultan, HJ Chaudhary (2019). Mechanistic elucidation of germination potential and growth of wheat inoculated with exopolysaccharide and ACCdeaminase producing Bacillus strains under induced salinity stress. Ecotoxicol Environ Saf 183; Article 109466

Aneja KR (2003). Experiments in Microbiology Plant Pathology and Biotechnology $\left(4^{\text {th }}\right.$ edn $)$. New Delhi, India 
Berlemont R, AC Martiny (2013). Phylogenetic distribution of potential cellulases in bacteria. Appl Environ Microbiol 79:1545-1554

Cappuccino JC, N Sherman (1992). Microbiology: A Laboratory Manual ( $3^{\text {rd }}$ edn), pp: 125-179. Benjamin/Cummings Pub. Co., New York, USA

Devi SS, NG Devi, MC Kalita, NC Talukdar (2018). Isolation and selection of cellulose-degrading microorganisms for utilization along with earthworms in efficient conversion of municipality waste mix to compost. Curr Sci 114:1261-1274

Dhanasekaran D, S Selvamani, A Panneerselvam, N Thajuddin (2009). Isolation and characterization of actinomycetes in Vellar Estuary, Annagkoil, Tamil Nadu. Afr J Biotechnol 8:4159-4162

Elardo PSM, M Scheuermayer, S Kozytska, U Hentschel (2009). Streptomyces axinellae sp. isolated from the Mediterranean sponge. Axinella olypoides (Porifera). Intl J Syst Evol Microbiol 59:14331437

Etesami H, HA Alikhani, HM Hosseini (2015). Indole-3-acetic acid (IAA) production trait, a useful screening to select endophytic and rhizosphere competent bacteria for rice growth promoting agents. Methods X 2:72-78

Frey-Klett P, M Chavatte, ML Clausse, S Courrier, C Le Roux, J Raaijmakers, MG Martinotti, JC Pierrat, J Garbaye (2005). Ectomycorrhizal symbiosis affects functional diversity of rhizosphere fluorescent pseudomonads. New Phytol 165:317-328

Gonzalo DG, DI Colpa, MHM Habib, MW Fraaije (2016). Bacterial enzymes involved in lignin degradation. J Biotechnol 236:110-119

Gopalakrishnan S, S Pande, M Sharma, P Humayun, BK Kiran, D Sandeep, MS Vidya, K Deepthi, O Rupela (2011). Evaluation of actinomycete isolates obtained from herbal vermicompost for biological control of Fusarium wilt of chickpea. Crop Prot 30:1070-1078

Haruta S, Z Cui, Z Huang, M Li, M Ishii, Y Igarashi (2002). Construction of a stable microbial community with high cellulose degradation ability. Appl Microbiol Biotech 59:529-534

Hussain AA, MS Abdel-Salam, HH Abo-Ghalia, WK Hegazy, SS Hafez (2017). Optimization and molecular identification of novel cellulose degrading bacteria isolated from Egyptian environment. J Genet Eng Biotechnol 15:77-85

Jeong MJ, AL Dupont, ER de la Rie (2012). Degradation of cellulose at the wet-dry interface: I -study of the depolymerization. Cellulose 19:1135-1147

Jurado M, MJ López, F Suárez-Estrella, MC Vargas-García, JA LópezGonzález, J Moreno (2014). Exploiting composting biodiversity: study of the persistent and biotechnologically relevant microorganisms from lignocellulose-based composting. Bioresour Technol 162:283-293

Kasing A (1995). Cellulase Production, Practical Biotechnology. Sarawak, Malaysia

Koushalshahi MB, Kh Issazadeh, A Tehranifard, MRMK Pahlaviani, A Massiha (2012). Isolation of $\mathrm{Hg}$ and $\mathrm{Cu}$ resistant Streptomyces from marine sediments in different regions of the Caspian Sea. Afr J Microbiol Res 6:4048-4052

Levi N, AM Khenkin, B Hailegnaw, R Neumann (2016). Depolymerization of cellulose in water catalyzed by phenylboronic acid derivatives. ACS Sust Chem Eng 4:5799-5803
Olson DG, JE McBride, AJ Shaw, LR Lynd (2012). Recent progress in consolidated bioprocessing. Curr Opin Biotechnol 23:396-405

Page AL, RH Miller, DR Kenney (1982). Methods of Soil Analysis, Part 2. Chemical and Microbiological Properties, $2^{\text {nd }}$ edn. American Society of Agronomy, Madison, Wisconsin, USA

Poopal AC, RS Laxman (2009). Studies on the biological reduction of chromate by Streptomyces griseous. J Haz Mat 169:539-45

Prasad P, T Singh, Sh Bedi (2013). Characterization of the cellulolytic enzyme produced by Streptomyces griseorubens (Accession No. AB184139) isolated from Indian soil. J King Saud Univ Sci 25:245250

Sanchez OJ, DA Ospina, S Montoya (2017). Compost supplementation with nutrients and microorganisms in composting process. Waste Manage 69:136-153

Saratale GD, RG Saratale, SE Oh (2012). Production and characterization of multiple cellulolytic enzymes by isolated Streptomyces sp. MDS. Biomass Bioener 47:302-215

Schwyn B, JB Neilands (1987). Universal chemical assay for the detection and determination of siderophores. Anal Biochem 160:47-56

Soares MM, R da Silva, EC Carmona, E Gomes (2001). Pectinolytic enzyme production by Bacillus species and their potential application on juice extraction. J Microbiol Biotechnol 17:79-82

Soeka YS, S Nandang, T Evi, T Yulinery (2019). Characterization of Cellulase Enzyme Produced by Two Selected Strains of Streptomyces macrosporeus Isolated from Soil in Indonesia. Makara J Sci 23:65-71

Soriano M, P Diaz, FIJ Pastor (2000). Pectinolytic systems of two aerobic sporogenous bacterial strains with high activity on pectin. Curr Microbiol 50:114-118

Sreevidya M, S Gopalakrishnan, H Kudapa, RK Varshney (2016). Exploring plant growth-promotion actinomycetes from vermicompost and rhizosphere soil for yield enhancement in chickpea. Braz J Microbiol 47:85-95

Stamenov D, S Đurić, T Hajnal-Jafari, D Jošić, M Manojlović (2016). The use of Streptomyces isolate with plant growth promoting traits in the production of English ryegrass. Rom Agric Res 33, www.incdafundulea.ro DII 2067-5720 RAR 2016-70

Stamenov D (2013). Karakterizacija mikroorganizama promotora rasta i njihovo preživljavanje u rizosferi engleskog ljulja. Doctoral Degree Dissertation Doktorska disertacija. Univerzitet u Novom Sadu, Poljoprivredni fakultet (in Serbian)

Varma VS, S Das, CV Sastri, AS Kalamdhad (2017). Microbial degradation of lignocellulosic fractions during drum composting of mixed organic waste. Sustain Environ Res 27:265-272

Zhao Y, Q Lu, Y Wei, H Cui, X Zhang, X Wang, S Shan, Z Wei (2016). Effect of actinobacteria agent inoculation methods on cellulose degradation during composting based on redundancy analysis. Bioresour Technol 219:196-203

Zhao Y, Y Zhao, Z Zhang, Y Wei, H Wang, Q Lu, Y Li, Z Wei (2017). Effect of thermo-tolerant actinomycetes inoculation on cellulose degradation and the formation of humic substances during composting. Waste Manage 68:64-73 